\title{
Budidaya Padi Organik dengan Waktu Aplikasi Pupuk Kandang yang Berbeda dan Pemberian Pupuk Hayati
}

\author{
Rice Organic Cultivation with Different Times of Manure Application and Biological Fertilizer \\ Application
}

\author{
Muchamad Hartanto, Maya Melati*
}

Departemen Agronomi dan Hortikultura, Fakultas Pertanian, Institut Pertanian Bogor (Bogor Agricultural University), Jl. Meranti, Kampus IPB Darmaga, Bogor 16680, Indonesia Telp.\&Faks.62-251-8629353 e-mail agronipb@indo.net.id *Penulis untuk korespondensi: maya_melati05@yahoo.com

Disetujui 24 Desember 2013/ Published Online 10 Januari 2014

\begin{abstract}
The experiment was conducted at Cikarawang, Dramaga, Bogor from November 2012 to March 2013. This study aims to determine the most appropriate time in manure application and bio-fertilizer. The experiment used split plot experimental design; it consisted of two factors and 4 replications. The first factor, as sub plot, was time of chicken manure application with 4 treatments i.e. application of 10 tons chicken manure/ha applied 2 weeks before planting, 10 tons/ha applied 4 weeks after planting, 10 tons/ha applied 6 weeks after planting, and split application of 5 tons/ha applied 2 weeks before planting and 5 tons/ha 4 weeks after planting. The second factor, as main plot, was application of bio-fertilizer (with and without biofertilizer). The highest rice yield (5.04 tons dry grains/ha) was found from the split application of 5 tons chicken manure/ha 2 weeks before planting and 5 tons/ha at 4 weeks after planting with additional biofertilizer.Those yield was not significantly different with 4.72 tons dry grains/ha from the application of 10 tons manure/ha at 2 weeks before planting, without bio-fertilizer.
\end{abstract}

Keywords: chicken manure, organic farming, organic fertilizer

\section{ABSTRAK}

Percobaan dilaksanakan di Cikarawang, Dramaga, Bogor dari bulan November 2012 hingga Maret 2013. Penelitian ini bertujuan untuk mengetahui waktu yang paling tepat dalam pemberian pupuk kandang dan pemberian pupuk hayati. Percobaan ini menggunakan rancangan percobaan secara split plot dan rancangan lingkungannya adalah Rancangan Kelompok Lengkap, terdiri atas 2 faktor dan 4 ulangan. Faktor pertama, sebagai anak petak, adalah waktu aplikasi pupuk kandang ayam dengan 4 perlakuan yaitu, aplikasi pupuk kandang 10 ton/ha yang diberikan saat 2 minggu sebelum tanam, 10 ton/ha yang diberikan saat 4 minggu setelah tanam, 10 ton/ha yang diberikan saat 6 minggu setelah tanam, dan aplikasi bertahap 5 ton/ha yang diberikan saat 2 minggu sebelum tanam dan 5 ton/ha saat 4 minggu setelah tanam. Faktor ke2, sebagai petak utama, adalah pemberian pupuk hayati dengan 2 perlakuan (dengan dan tanpa pupuk hayati). Produktivitas padi paling tinggi (5.04 ton GKG/ha) diperoleh dari perlakuan aplikasi bertahap 5 ton pupuk kandang /ha saat 2 minggu sebelum tanam dan 5 ton pupuk kandang /ha saat 4 minggu setelah tanam dengan tambahan pupuk hayati. Produktivitas tersebut tidak berbeda nyata dengan 4.72 ton GKG/ha akibat aplikasi 10 ton pupuk kandang/ha pada 2 minggu sebelum tanam, tanpa pupuk hayati.

Kata kunci: pertanian organik, pupuk organik, pupuk kandang ayam

\section{PENDAHULUAN}

Padi merupakan tanaman pangan utama di Indonesia. Kebutuhan tanaman ini sangat penting di Indonesia karena rata-rata orang di Indonesia memakan nasi sebagai makanan utama.

Padi dapat dibudidayakan secara organik. Budidaya secara organik adalah memberi masukan bahan organik ke dalam tanah yang selanjutnya 
melalui mekanisme alam, tanah tersebut memberikan masukan unsur hara kepada tanaman. Budidaya secara organik pada awalnya menghasilkan produksi yang rendah namun memberikan dampak yang positif dalam keberlanjutan penanaman. Menurut Bawlye dan Shyam (2008) padi organik adalah padi yang disahkan oleh sebuah badan independen, untuk ditanam dan diolah menurut standar "organik" yang ditetapkan.

Pupuk kandang adalah salah satu jenis bahan organik yang dapat diaplikasikan ke tanah untuk mendukung pertumbuhan tanaman dalam budidaya organik. Menurut Dardak (1982) pupuk kandang adalah pupuk yang dihasilkan dari hewan yang mengandung bahan organik dan sumber energi bagi mikroorganisme yang ada di tanah. Menurut Simatupang (1990) jika dibandingkan dengan pupuk kimia, pupuk kandang lebih lambat reaksinya namun dalam jangka panjang memberikan hasil yang lebih baik.

Pupuk hayati juga diperbolehkan dalam budidaya organik untuk mendukung pertumbuhan tanaman. Menurut Balai Penelitian Tanah (2005) pupuk hayati disebut juga pengurai, yaitu organisme yang bertugas merombak sisa-sisa organisme lain untuk memperoleh makanannya. Adanya perombak ini memungkinkan zat-zat organik terurai dan mengalami daur ulang kembali menjadi hara yang dapat diserap oleh tanaman.

Berdasarkan komunikasi pribadi dengan Sudarsono, Pratiwi, dan Nurrahma pada tahun 2012, diperoleh informasi bahwa setelah memasukkan input pupuk kandang sebanyak 1020 ton ke dalam lahan pada 2 minggu sebelum tanam ternyata terlihat gejala defisiensi unsur hara yang ditandai dengan daun yang menguning sehingga masih perlu tambahan pupuk kandang ke dalam tanah pada saat 4 minggu setelah tanam. Pengetahuan yang diperoleh yaitu petani biasanya memberikan pupuk kandang pada saat 4 minggu setelah tanam. Praktek aplikasi pupuk menunjukkan adanya keragaman dan waktu aplikasi pupuk kandang. Oleh karena itu tujuan penelitian ini adalah untuk mengoptimalkan pemupukan dengan cara mengetahui waktu yang paling tepat dalam pemberian pupuk kandang dan pemberian pupuk hayati.

\section{BAHAN DAN METODE}

Percobaan dilaksanakan pada bulan November 2012 sampai bulan Maret 2013. Tempat percobaan adalah di Kebun Percobaan IPB
Cikarawang, Kabupaten Bogor, Provinsi Jawa Barat.

Bahan tanam yang digunakan adalah benih padi varietas Ciherang. Pupuk yang digunakan adalah pupuk kandang ayam petelur. Pupuk hayati yang digunakan mengandung mikroba Bacillus sp., Pseudomonas sp., Rhizobium sp., Azotobacter sp., dan Azospirillum sp..

Percobaan ini menggunakan rancangan split plot dengan rancangan lingkungan Rancangan Kelompok Lengkap Teracak (RKLT), terdiri atas 2 faktor yaitu waktu aplikasi pemupukan dan pemberian pupuk hayati. Perlakuan diulang sebanyak 4 kali.

Faktor pertama, sebagai anak petak, adalah waktu aplikasi pupuk kandang ayam dengan 4 perlakuan yaitu, aplikasi pupuk kandang 10 ton/ha yang diberikan saat 2 minggu sebelum tanam, 10 ton/ha yang diberikan saat 4 minggu setelah tanam, 10 ton/ha yang diberikan saat 6 minggu setelah tanam, dan aplikasi secara bertahap 5 ton/ha yang diberikan saat 2 minggu sebelum tanam dan 5 ton/ha saat 4 minggu setelah tanam. Faktor ke-2, sebagai petak utama, adalah pemberian pupuk hayati dengan 2 perlakuan (dengan dan tanpa pupuk hayati).

Data hasil pengamatan ini diolah dengan software SAS system dan dilakukan uji lanjut dengan perbandingan ganda DUNCAN (DMRT) pada taraf $5 \%$ apabila hasil perlakuan berpengaruh nyata (Gomez dan Gomez, 1995).

Persemaian benih dilaksanakan 3 minggu sebelum tanam. Luas lahan untuk persemaian benih padi sekitar 4-5\% dari luas bahan tanam dengan lebar 1-2 $\mathrm{m}$.

Bibit yang telah siap tanam kemudian ditanam di sawah dengan sistem legowo 3:1 berjarak $15 \mathrm{~cm} \times 25 \mathrm{~cm} \times 50 \mathrm{~cm}$, tiap lubang tanam ditanami 3 bibit setelah berumur 3 minggu dari persemaian. Ukuran petak percobaan adalah 4 $\mathrm{m} \times 3 \mathrm{~m}$.

Pemanenan dilakukan 30-35 hari setelah berbunga atau melihat tanda kematangan gabah. Tanda kematangan gabah terlihat jika hampir 90$95 \%$ gabah sudah menguning.

Peubah diamati pada 10 tanaman contoh di tiap satuan percobaan. Peubah yang diamati meliputi pengamatan vegetatif dan generatif yaitu tinggi tanaman $(\mathrm{cm})$, jumlah anakan, warna daun, panjang akar $(\mathrm{cm})$, bobot kering dan basah biomassa akar dan tajuk (g), jumlah anakan produktif, panjang malai $(\mathrm{cm})$, jumlah gabah per malai, bobot basah dan kering gabah per tanaman (g), persentase gabah isi dan hampa (\%), bobot 1,000 butir, bobot petak bersih basah dan kering 
(g), potensi hasil dan produktivitas (ton ha ${ }^{-1}$ ) dan kadar hara N, P dan K pada daun (\%).

Seluruh tanaman padi terkena serangan hawar daun bakteri (bacterial leaf blight) atau penyakit kresek yang disebabkan oleh bakteri Xanthomonas campestris pv. oryzae. Pengendalian dilakukan dengan menyemprotkan agen hayati Corrynebacterium pada saat tanaman berumur 6 MST. Setelah disemprotkan Corrynebacterium gejala serangan berkurang dan terlihat tanaman mulai tumbuh dengan baik.

\section{HASIL DAN PEMBAHASAN}

\section{Hasil}

\section{Analisis Tanah Awal}

Hasil analisis tanah sebelum percobaan menunjukkan $\mathrm{pH}$ tanah netral (5.9). Menurut Handayanto dan Hairiah (2007) tingkat kemasaman $(\mathrm{pH})$ tanah penting karena organisme tanah dan tanaman sangat responsif terhadap sifat kimia di lingkungannya. Kandungan C-organik dan N-Total rendah, yaitu $1.68 \%$ dan $0.17 \%$. Nilai P dan K tanah yang mencapai 104.8 ppm dan
248 ppm sudah dapat tergolong tinggi sedangkan nilai KTK sebesar 20.03 me/100 g masih dikategorikan sedang.

Pengaruh Waktu Aplikasi Pupuk Kandang terhadap Komponen Pertumbuhan dan Hasil Tanaman

Aplikasi pupuk kandang berpengaruh nyata terhadap beberapa pengamatan pertumbuhan (Tabel 1). Pengamatan tinggi tanaman berbeda nyata pada minggu ke-5. Perlakuan aplikasi pupuk kandang secara bertahap pada saat 2 minggu sebelum tanam dan 4 minggu setelah tanam dapat memberikan hasil yang lebih baik pada tinggi tanaman dan panjang akar tanaman. Pemberian pupuk kandang 4 minggu setelah tanam dapat memberikan hasil yang lebih maksimal pada bobot basah dan bobot kering tajuk saat tanaman berumur 4 minggu setelah tanam. Pertambahan jumlah anakan mulai terhenti pada saat tanaman berumur 6 minggu setelah tanam karena pada saat pengamatan 7 minggu setelah tanam jumlahnya tidak jauh berbeda.

Tabel 1. Komponen pertumbuhan tanaman pada perlakuan aplikasi pupuk kandang

\begin{tabular}{|c|c|c|c|c|c|c|c|c|c|c|}
\hline \multirow{3}{*}{$\begin{array}{l}\text { Peubah } \\
\text { Tinggi tanaman }(\mathrm{cm})\end{array}$} & \multirow{4}{*}{$\begin{array}{c}\begin{array}{c}\text { Umur } \\
(\mathrm{MST})\end{array} \\
4 \\
5\end{array}$} & \multicolumn{8}{|c|}{ Waktu aplikasi pupuk } & \multirow{4}{*}{$\begin{array}{c}\text { Rata-rata } \\
56.70 \\
67.47\end{array}$} \\
\hline & & \multicolumn{2}{|c|}{$\begin{array}{l}10 \text { ton/ha } \\
-2 \mathrm{MST}\end{array}$} & \multicolumn{2}{|c|}{$\begin{array}{l}10 \text { ton/ha } \\
+4 \mathrm{MST}\end{array}$} & \multicolumn{2}{|c|}{$\begin{array}{c}10 \text { ton/ha + } 6 \\
\mathrm{MST}\end{array}$} & \multicolumn{2}{|c|}{$\begin{array}{l}5 \text { ton/ha }-2 \mathrm{MST} \\
5 \text { ton/ha }+4 \mathrm{MST}\end{array}$} & \\
\hline & & 56.24 & & 59.25 & & 52.55 & & 58.78 & & \\
\hline & & 67.88 & $a b$ & 68.76 & a & 63.28 & $\mathrm{~b}$ & 69.76 & a & \\
\hline \multirow[t]{5}{*}{ Jumlah anakan per rumpun } & 3 & 10.1 & & 9.0 & & 8.9 & & 9.1 & & 9.3 \\
\hline & 4 & 13.5 & & 12.1 & & 11.9 & & 12.7 & & 12.5 \\
\hline & 5 & 13.6 & & 12.5 & & 12.4 & & 12.9 & & 12.8 \\
\hline & 6 & 13.7 & & 13.1 & & 13.2 & & 13.8 & & 13.4 \\
\hline & 7 & 13.7 & & 12.0 & & 13.0 & & 13.3 & & 13.0 \\
\hline \multirow[t]{2}{*}{ Warna daun } & 3 & 3.50 & & 3.50 & & 3.50 & & 3.50 & & 3.50 \\
\hline & 4 & 3.50 & & 3.50 & & 3.50 & & 3.50 & & 3.50 \\
\hline \multirow[t]{2}{*}{ Panjang akar (cm) } & 4 & 11.75 & $\mathrm{~b}$ & 15.00 & $a b$ & 16.01 & $a b$ & 16.51 & a & 14.82 \\
\hline & 8 & 34.14 & & 31.24 & & 30.38 & & 31.29 & & 31.76 \\
\hline \multirow[t]{3}{*}{ Panjang tajuk (cm) } & 4 & 46.88 & & 56.80 & & 51.66 & & 54.48 & & 52.45 \\
\hline & 6 & 77.51 & & 79.54 & & 75.28 & & 78.93 & & 77.81 \\
\hline & 8 & 92.19 & & 95.50 & & 88.84 & & 92.55 & & 92.27 \\
\hline \multirow[t]{4}{*}{ Bobot basah akar (g/tanaman) } & 4 & 2.40 & & 6.11 & & 5.43 & & 4.04 & & 4.50 \\
\hline & 6 & 33.16 & & 22.34 & & 23.98 & & 25.78 & & 26.32 \\
\hline & 8 & 22.26 & & 21.38 & & 21.50 & & 16.22 & & 20.34 \\
\hline & 14 & 19.38 & & 17.50 & & 22.88 & & 14.13 & & 18.47 \\
\hline \multirow[t]{4}{*}{ Bobot kering akar (g/tanaman) } & 4 & 1.01 & & 2.13 & & 2.66 & & 1.25 & & 1.76 \\
\hline & 6 & 17.54 & & 8.94 & & 11.01 & & 11.03 & & 12.13 \\
\hline & 8 & 10.00 & & 9.50 & & 11.88 & & 7.25 & & 9.66 \\
\hline & 14 & 9.00 & & 8.50 & & 11.25 & & 6.25 & & 8.75 \\
\hline \multirow[t]{4}{*}{ Bobot basah tajuk (g/tanaman) } & 4 & 6.64 & $\mathrm{~b}$ & 23.25 & a & 15.13 & $a b$ & 17.21 & $a b$ & 15.56 \\
\hline & 6 & 73.94 & & 67.00 & & 70.79 & & 96.17 & & 76.98 \\
\hline & 8 & 105.14 & & 116.50 & & 91.50 & & 91.38 & & 101.13 \\
\hline & 14 & 60.25 & & 71.25 & & 58.13 & & 53.13 & & 60.69 \\
\hline \multirow[t]{4}{*}{ Bobot kering tajuk (g/tanaman) } & 4 & 1.64 & $\mathrm{~b}$ & 4.47 & $\mathrm{a}$ & 3.50 & $a b$ & 3.24 & $a b$ & 3.21 \\
\hline & 6 & 14.77 & & 16.24 & & 15.43 & & 21.73 & & 17.04 \\
\hline & 8 & 29.00 & & 35.50 & & 28.75 & & 25.00 & & 29.56 \\
\hline & 14 & 30.00 & & 36.38 & & 29.75 & & 26.00 & & 30.53 \\
\hline $\mathrm{K}$ daun $(\%)$ & 14 & 2.70 & & 2.39 & & 2.57 & & 2.44 & & 2.53 \\
\hline
\end{tabular}


Perbedaan aplikasi pupuk kandang berpengaruh nyata pada beberapa komponen hasil yang dilakukan pada tanaman padi (Tabel 2).
Perlakuan aplikasi pupuk kandang pada saat 2 minggu sebelum tanam dapat menyebabkan persentase gabah isi padi paling tinggi.

Tabel 2. Komponen hasil tanaman pada perlakuan aplikasi pupuk kandang

\begin{tabular}{|c|c|c|c|c|c|}
\hline \multirow[b]{2}{*}{ Peubah } & \multicolumn{4}{|c|}{ Waktu aplikasi pupuk } & \multirow[b]{2}{*}{$\begin{array}{c}\text { Rata- } \\
\text { rata }\end{array}$} \\
\hline & $\begin{array}{l}10 \text { ton/ha - } \\
2 \mathrm{MST}\end{array}$ & $\begin{array}{c}10 \text { ton } / \text { ha }+ \\
4 \mathrm{MST}\end{array}$ & $\begin{array}{l}10 \text { ton/ha }+ \\
6 \mathrm{MST}\end{array}$ & $\begin{array}{c}5 \text { ton/ha }-2 \mathrm{MST} \\
5 \text { ton/ha }+4 \mathrm{MST}\end{array}$ & \\
\hline Jumlah anakan produktif & 11.4 & 10.3 & 11.1 & 11.5 & 11.1 \\
\hline Gabah isi $(\%)$ & 81.88 & 74.13 & 71.28 & 74.73 & 75.51 \\
\hline Gabah hampa $(\%)$ & 18.12 & 25.87 & 28.72 & 25.27 & 24.49 \\
\hline Bobot basah gabah (g/tanaman) & 323.50 & 210.50 & 261.00 & 264.13 & 264.78 \\
\hline Bobot basah gabah ubinan $\left(\mathrm{kg} / 6.25 \mathrm{~m}^{2}\right)$ & 3.30 & 3.30 & 2.74 & 3.31 & 3.16 \\
\hline Produktivitas GKP & 5.28 & 5.28 & 4.38 & 5.30 & 5.06 \\
\hline
\end{tabular}

\section{(ton/ha)}

Keterangan: Angka yang diikuti huruf yang sama pada baris yang sama menunjukkan hasil yang tidak berbeda nyata menurut uji DMRT 5\%.

Pengaruh Pemberian Pupuk Hayati terhadap Komponen Pertumbuhan Tanaman dan Komponen Hasil Tanaman
Pemberian pupuk hayati tidak berpengaruh nyata pada semua pengamatan komponen pertumbuhan dan komponen hasil yang dilakukan pada tanaman padi (Tabel 3 dan 4).

Tabel 3. Komponen pertumbuhan tanaman pada perlakuan pupuk hayati

\begin{tabular}{|c|c|c|c|c|}
\hline \multirow{2}{*}{ Peubah } & \multirow{2}{*}{ Umur (MST) } & \multicolumn{2}{|c|}{ Pupuk hayati } & \multirow{2}{*}{ Rata-rata } \\
\hline & & Dengan & Tanpa & \\
\hline \multirow[t]{2}{*}{ Tinggi tanaman $(\mathrm{cm})$} & 4 & 56.95 & 56.46 & 56.70 \\
\hline & 5 & 67.38 & 67.46 & 67.42 \\
\hline \multirow[t]{3}{*}{ Jumlah anakan per rumpun } & 3 & 9.4 & 9.2 & 9.3 \\
\hline & 5 & 12.5 & 13.2 & 12.8 \\
\hline & 7 & 12.9 & 13.1 & 13.0 \\
\hline \multirow[t]{2}{*}{ Warna daun } & 3 & 3.50 & 3.50 & 3.50 \\
\hline & 4 & 3.50 & 3.50 & 3.50 \\
\hline \multirow[t]{2}{*}{ Panjang akar } & 4 & 14.21 & 15.43 & 14.82 \\
\hline & 8 & 30.23 & 33.29 & 31.76 \\
\hline \multirow[t]{3}{*}{ Panjang tajuk } & 4 & 51.25 & 53.66 & 52.45 \\
\hline & 6 & 77.43 & 78.20 & 77.81 \\
\hline & 8 & 94.08 & 90.46 & 92.27 \\
\hline \multirow[t]{4}{*}{ Bobot basah akar (g/tanaman) } & 4 & 4.50 & 4.49 & 4.50 \\
\hline & 6 & 29.89 & 22.75 & 26.32 \\
\hline & 8 & 22.08 & 18.60 & 20.34 \\
\hline & 14 & 19.25 & 17.69 & 18.47 \\
\hline \multirow{4}{*}{ Bobot kering akar (g/tanaman) } & 4 & 1.73 & 1.80 & 1.76 \\
\hline & 6 & 14.95 & 9.31 & 12.13 \\
\hline & 8 & 10.06 & 9.25 & 9.66 \\
\hline & 14 & 9.19 & 8.31 & 8.75 \\
\hline \multirow[t]{4}{*}{ Bobot basah tajuk (g/tanaman) } & 4 & 16.28 & 14.84 & 15.56 \\
\hline & 6 & 78.36 & 75.60 & 76.98 \\
\hline & 8 & 106.16 & 96.10 & 101.13 \\
\hline & 14 & 59.63 & 61.75 & 60.69 \\
\hline \multirow[t]{4}{*}{ Bobot kering tajuk (g/tanaman) } & 4 & 3.20 & 3.22 & 3.21 \\
\hline & 6 & 18.16 & 15.92 & 17.04 \\
\hline & 8 & 28.69 & 30.44 & 29.56 \\
\hline & 14 & 29.63 & 31.44 & 30.53 \\
\hline $\mathrm{K}$ daun $(\%)$ & 14 & 2.54 & 2.51 & 2.53 \\
\hline
\end{tabular}


Tabel 4. Komponen hasil tanaman pada perlakuan pupuk hayati

\begin{tabular}{lccc}
\hline \multirow{2}{*}{ Peubah } & \multicolumn{2}{c}{ Pupuk hayati } & \multirow{2}{*}{ Rata-rata } \\
\cline { 2 - 3 } & Dengan & Tanpa & \\
\hline Jumlah anakan produktif & 11.0 & 11.2 & 11.1 \\
Gabah isi (\%) & 75.69 & 75.32 & 75.51 \\
Gabah hampa (\%) & 24.31 & 24.68 & 24.49 \\
Bobot basah gabah (g/tanaman) & 263.81 & 265.75 & 264.78 \\
Bobot basah gabah ubinan $\left(\mathrm{kg} / 6.25 \mathrm{~m}^{2}\right)$ & 3.15 & 3.18 & 3.16 \\
Produktivitas GKP (ton/ha) & 5.04 & 5.08 & 5.06 \\
\hline
\end{tabular}

Pengaruh Interaksi antara Waktu Aplikasi Pemberian Pupuk Kandang dan Pemberian Pupuk Hayati terhadap Komponen Pertumbuhan dan Hasil Tanaman

Interaksi antara waktu pemberian pupuk kandang dan pemberian pupuk hayati berpengaruh nyata pada beberapa komponen pertumbuhan tanaman padi (Tabel 5). Interaksi aplikasi pupuk kandang pada saat 6 minggu setelah tanam dengan pupuk hayati memberikan nilai paling rendah pada pengamatan tinggi tanaman, jumlah anakan dan warna daun. Pemberian pupuk kandang pada 2 minggu sebelum tanam dengan penambahan pupuk hayati menyebabkan kadar $\mathrm{N}$ dan $\mathrm{P}$ daun tertinggi.

Tabel 5. Pengaruh interaksi perlakuan aplikasi pupuk kandang dengan pupuk hayati terhadap komponen pertumbuhan tanaman

\begin{tabular}{|c|c|c|c|c|c|c|}
\hline \multirow[b]{2}{*}{ Aplikasi pupuk hayati } & \multicolumn{6}{|c|}{ Waktu aplikasi pupuk } \\
\hline & \multicolumn{2}{|c|}{$\begin{array}{l}10 \text { ton/ha } \\
-2 \mathrm{MST}\end{array}$} & $\begin{array}{l}10 \text { ton } / \mathrm{ha} \\
+4 \mathrm{MST}\end{array}$ & $\begin{array}{l}10 \text { ton/ha } \\
+6 \mathrm{MST}\end{array}$ & \multicolumn{2}{|c|}{$\begin{array}{c}5 \text { ton/ha - } 2 \mathrm{MST} \\
5 \text { ton/ha }+4 \mathrm{MST}\end{array}$} \\
\hline & \multicolumn{6}{|c|}{ Tinggi tanaman 3 MST $(\mathrm{cm})$} \\
\hline Dengan & 42.28 & $a b$ & $44.90 \mathrm{ab}$ & $42.08 \mathrm{ab}$ & 45.55 & a \\
\hline \multirow[t]{2}{*}{ Tanpa } & 43.70 & $\mathrm{ab}$ & $44.60 \mathrm{ab}$ & $38.75 \quad b$ & 42.33 & $a b$ \\
\hline & \multicolumn{6}{|c|}{ Tinggi tanaman 6 MST $(\mathrm{cm})$} \\
\hline Dengan & 78.40 & $\mathrm{a}$ & $77.88 \quad \mathrm{a}$ & $70.90 \quad \mathrm{~b}$ & 79.80 & $\mathrm{a}$ \\
\hline \multirow{2}{*}{ Tanpa } & 77.48 & $a b$ & $76.80 \quad a b$ & $73.65 \mathrm{ab}$ & 77.38 & $a b$ \\
\hline & \multicolumn{6}{|c|}{ Tinggi tanaman 7 MST $(\mathrm{cm})$} \\
\hline Dengan & 83.40 & $\mathrm{a}$ & 83.33 a & $75.38 \quad \mathrm{~b}$ & 85.73 & $\mathrm{a}$ \\
\hline \multirow[t]{2}{*}{ Tanpa } & 82.95 & a & $82.65 \mathrm{a}$ & $78.90 \mathrm{ab}$ & 83.63 & $\mathrm{a}$ \\
\hline & \multicolumn{6}{|c|}{ Tinggi tanaman 8 MST (cm) } \\
\hline Dengan & 86.93 & $a b$ & $89.35 \mathrm{a}$ & $80.13 \mathrm{~b}$ & 90.43 & $\mathrm{a}$ \\
\hline \multirow[t]{2}{*}{ Tanpa } & 86.68 & $a b$ & $85.48 \quad a b$ & 83.88 ab & 86.88 & $a b$ \\
\hline & \multicolumn{6}{|c|}{ Jumlah anakan per rumpun 8 MST $(\mathrm{cm})$} \\
\hline Dengan & 21.5 & $\mathrm{a}$ & $21.4 \mathrm{a}$ & $15.5 \mathrm{~b}$ & 19.6 & $a b$ \\
\hline \multirow[t]{2}{*}{ Tanpa } & 18.8 & $\mathrm{ab}$ & $15.6 \mathrm{~b}$ & $21.7 \quad \mathrm{a}$ & 21.2 & $a b$ \\
\hline & \multicolumn{6}{|c|}{ Warna daun 5 MST $(\mathrm{cm})$} \\
\hline Dengan & 3.50 & $\mathrm{~b}$ & $3.50 \mathrm{~b}$ & $3.00 \mathrm{c}$ & 4.00 & $\mathrm{a}$ \\
\hline \multirow[t]{2}{*}{ Tanpa } & 3.50 & $\mathrm{~b}$ & $3.50 \mathrm{~b}$ & $3.00 \mathrm{c}$ & 4.00 & $\mathrm{a}$ \\
\hline & \multicolumn{6}{|c|}{ Warna daun 6 MST $(\mathrm{cm})$} \\
\hline Dengan & 3.00 & $\mathrm{c}$ & $3.50 \mathrm{~b}$ & $2.50 \mathrm{~d}$ & 4.00 & $\mathrm{a}$ \\
\hline \multirow[t]{2}{*}{ Tanpa } & 3.00 & $\mathrm{c}$ & $3.50 \mathrm{~b}$ & $2.50 \mathrm{~d}$ & 4.00 & a \\
\hline & \multicolumn{6}{|c|}{ Warna daun 7 MST $(\mathrm{cm})$} \\
\hline Dengan & 4.00 & $\mathrm{a}$ & 4.00 & $3.50 \mathrm{~b}$ & 4.00 & $\mathrm{a}$ \\
\hline Tanpa & 4.00 & $\mathrm{a}$ & 4.00 & $3.50 \mathrm{~b}$ & 4.00 & a \\
\hline
\end{tabular}


Tabel 5. (lanjutan)

\begin{tabular}{|c|c|c|c|c|c|c|c|c|}
\hline \multirow[b]{2}{*}{ Aplikasi pupuk hayati } & \multicolumn{8}{|c|}{ Waktu aplikasi pupuk } \\
\hline & \multicolumn{2}{|c|}{$\begin{array}{l}10 \text { ton/ha } \\
-2 \mathrm{MST}\end{array}$} & \multicolumn{2}{|c|}{$\begin{array}{l}10 \text { ton/ha } \\
+4 \mathrm{MST}\end{array}$} & \multicolumn{2}{|c|}{$\begin{array}{l}10 \text { ton/ha } \\
+6 \mathrm{MST}\end{array}$} & \multicolumn{2}{|c|}{$\begin{array}{c}5 \text { ton/ha }-2 \mathrm{MST} \\
5 \text { ton/ha }+4 \mathrm{MST}\end{array}$} \\
\hline & \multicolumn{8}{|c|}{ Warna daun 8 MST $(\mathrm{cm})$} \\
\hline Dengan & 4.00 & a & 4.00 & $\mathrm{a}$ & 3.50 & $\mathrm{~b}$ & 4.00 & $\mathrm{a}$ \\
\hline \multirow[t]{2}{*}{ Tanpa } & 4.00 & $\mathrm{a}$ & 4.00 & $\mathrm{a}$ & 3.50 & $\mathrm{~b}$ & 4.00 & $\mathrm{a}$ \\
\hline & \multicolumn{8}{|c|}{ Panjang akar 6 MST $(\mathrm{cm})$} \\
\hline Dengan & 25.80 & $\mathrm{~b}$ & 28.75 & $\mathrm{ab}$ & 28.33 & $\mathrm{ab}$ & 29.18 & $a b$ \\
\hline \multirow[t]{2}{*}{ Tanpa } & 26.23 & $a b$ & 37.95 & $\mathrm{a}$ & 25.03 & $\mathrm{~b}$ & 27.38 & $a b$ \\
\hline & \multicolumn{8}{|c|}{$\mathrm{N}$ daun $(\%)$} \\
\hline Dengan & 1.87 & a & 1.43 & $a b$ & 1.30 & b & 1.34 & $\mathrm{~b}$ \\
\hline \multirow[t]{2}{*}{ Tanpa } & 1.47 & $a b$ & 1.42 & $a b$ & 1.61 & $a b$ & 1.62 & $a b$ \\
\hline & \multicolumn{8}{|c|}{$\mathrm{P}$ daun $(\%)$} \\
\hline Dengan & 0.36 & $\mathrm{a}$ & 0.33 & $\mathrm{ab}$ & 0.28 & $\mathrm{c}$ & 0.28 & $\mathrm{bc}$ \\
\hline Tanpa & 0.29 & $\mathrm{bc}$ & 0.26 & $\mathrm{c}$ & 0.26 & $\mathrm{c}$ & 0.25 & $\mathrm{c}$ \\
\hline
\end{tabular}

Keterangan: (*) Berbeda nyata pada taraf kesalahan 5\%; Angka yang diikuti huruf yang sama pada masing-masing peubah menunjukkan hasil yang tidak berbeda nyata menurut uji DMRT, $\alpha=5 \%$.

Interaksi antara waktu aplikasi pupuk kandang dan pemberian pupuk hayati berpengaruh nyata pada beberapa peubah komponen hasil tanaman padi. Pemberian pupuk kandang pada 4 minggu setelah tanam menyebabkan potensi hasil tanaman paling rendah. Perlakuan aplikasi pupuk kandang pada saat 6 minggu setelah tanam menyebabkan nilai paling tinggi pada jumlah gabah per malai dan bobot kering gabah/tanaman. Aplikasi pupuk kandang secara bertahap pada 2 minggu sebelum tanam dan 4 minggu setelah tanam dengan pupuk hayati memberikan hasil tertinggi pada bobot 1000 butir, bobot kering gabah ubinan, dan produktivitas GKG.

Tabel 6. Pengaruh interaksi perlakuan aplikasi pupuk kandang dengan pupuk hayati terhadap komponen hasil tanaman

\begin{tabular}{|c|c|c|c|c|c|c|c|c|}
\hline \multirow[b]{2}{*}{ Aplikasi pupuk hayati } & \multicolumn{8}{|c|}{ Aplikasi kombinasi pupuk kandang } \\
\hline & \multicolumn{2}{|c|}{$\begin{array}{l}10 \text { ton/ha } \\
-2 \mathrm{MST}\end{array}$} & \multicolumn{2}{|c|}{$\begin{array}{l}10 \text { ton/ha } \\
+4 \mathrm{MST}\end{array}$} & \multicolumn{2}{|c|}{$\begin{array}{l}10 \text { ton/ha } \\
+6 \mathrm{MST}\end{array}$} & \multicolumn{2}{|c|}{$\begin{array}{l}5 \text { ton/ha }-2 \mathrm{MST} \\
5 \text { ton/ha }+4 \mathrm{MST}\end{array}$} \\
\hline & \multicolumn{8}{|c|}{ Panjang malai $(\mathrm{cm})$} \\
\hline Dengan & 23.64 & $\mathrm{ab}$ & 24.46 & $\mathrm{a}$ & 22.07 & $\mathrm{c}$ & 23.74 & $\mathrm{ab}$ \\
\hline Tanpa & 23.23 & $\mathrm{~b}$ & 22.04 & $\mathrm{c}$ & 23.79 & $a b$ & 23.91 & $\mathrm{ab}$ \\
\hline \multirow[t]{2}{*}{ Rata-rata } & 23.44 & $\mathrm{ab}$ & 23.25 & $\mathrm{ab}$ & 22.93 & $\mathrm{~b}$ & 23.83 & $\mathrm{a}$ \\
\hline & \multicolumn{8}{|c|}{ Jumlah gabah per malai } \\
\hline Dengan & 129.00 & $a b c$ & 143.41 & $\mathrm{ab}$ & 115.17 & $\mathrm{c}$ & 143.09 & $\mathrm{ab}$ \\
\hline \multirow[t]{2}{*}{ Tanpa } & 134.00 & $\mathrm{abc}$ & 117.16 & $\mathrm{bc}$ & 147.17 & $\mathrm{a}$ & 128.23 & $a b c$ \\
\hline & \multicolumn{8}{|c|}{ Bobot 1000 butir (g) } \\
\hline Dengan & 28.65 & $a b$ & 28.43 & $a b$ & 27.60 & $\mathrm{ab}$ & 29.13 & a \\
\hline \multirow[t]{2}{*}{ Tanpa } & 28.78 & $\mathrm{ab}$ & 26.60 & $\mathrm{~b}$ & 27.75 & $\mathrm{ab}$ & 26.78 & $\mathrm{~b}$ \\
\hline & \multicolumn{8}{|c|}{ Gabah isi (\%) (interaksi tidak nyata) } \\
\hline Dengan & 82.66 & $\mathrm{a}$ & 74.27 & a & 71.52 & $\mathrm{a}$ & 74.308 & a \\
\hline Tanpa & 81.11 & $\mathrm{a}$ & 73.99 & a & 71.05 & a & 75.153 & a \\
\hline \multirow[t]{2}{*}{ Rata-rata } & 81.88 & & 74.13 & & 71.28 & & 74.73 & \\
\hline & \multicolumn{8}{|c|}{ Bobot kering gabah (g/tanaman) } \\
\hline Dengan & 264.00 & $a b$ & 209.50 & $\mathrm{ab}$ & 139.50 & $\mathrm{ab}$ & 210.25 & $a b$ \\
\hline \multirow[t]{2}{*}{ Tanpa } & 247.75 & $\mathrm{ab}$ & 128.25 & $\mathrm{~b}$ & 278.25 & $\mathrm{a}$ & 206.25 & $a b$ \\
\hline & \multicolumn{8}{|c|}{ Bobot kering gabah ubinan $\left(\mathrm{kg} / 6.25 \mathrm{~m}^{2}\right)$} \\
\hline Dengan & 2.18 & $\mathrm{abc}$ & 2.50 & $a b c$ & 1.95 & $\mathrm{c}$ & 3.15 & $\mathrm{a}$ \\
\hline Tanpa & 2.95 & $\mathrm{ab}$ & 2.38 & $a b c$ & 2.23 & $a b c$ & 2.13 & $\mathrm{bc}$ \\
\hline
\end{tabular}

Tabel 6. Lanjutan 


\begin{tabular}{|c|c|c|c|c|}
\hline \multirow[b]{2}{*}{ Aplikasi pupuk hayati } & \multicolumn{4}{|c|}{ Aplikasi kombinasi pupuk kandang } \\
\hline & $\begin{array}{l}10 \text { ton/ha } \\
-2 \text { MST }\end{array}$ & $\begin{array}{l}10 \text { ton/ha } \\
+4 \mathrm{MST}\end{array}$ & $\begin{array}{l}10 \text { ton/ha } \\
+6 \mathrm{MST}\end{array}$ & $\begin{array}{c}5 \text { ton } / \mathrm{ha}-2 \mathrm{MST} \\
5 \text { ton/ha }+4 \mathrm{MST}\end{array}$ \\
\hline & \multicolumn{4}{|c|}{ Produktivitas GKG (ton/ha) } \\
\hline Dengan & 3.48 & $4 a b c$ & $3.12 \mathrm{c}$ & 5.04 \\
\hline \multirow[t]{2}{*}{ Tanpa } & 4.72 & 3.8 & $3.56 \mathrm{abc}$ & 3.4 \\
\hline & \multicolumn{4}{|c|}{ Potensi hasil (ton/ha) } \\
\hline Dengan & 7.02 & 7.90 & $4.91 \mathrm{ab}$ & 7.21 \\
\hline Tanpa & 6.80 & 4.59 & 8.07 & 6.90 \\
\hline
\end{tabular}

Keterangan: Angka yang diikuti huruf yang sama pada masing-masing peubah menunjukkan hasil yang tidak berbeda nyata menurut uji DMRT, $\alpha=5 \%$.

\section{Korelasi Antara Komponen Pertumbuhan terhadap Komponen Produksi}

Korelasi dilakukan untuk mengetahui keterkaitan antar peubah. Peubah bobot 1000 butir dan bobot gabah per tanaman berkorelasi nyata positif terhadap produktivitas GKG (Tabel 7).
Jumlah anakan produktif, panjang malai, dan jumlah gabah per malai memiliki korelasi yang nyata positif dengan potensi hasil padi. Korelasi yang nyata dan positif dapat diartikan terdapat hubungan peningkatan salah satu peubah tersebut meningkatkan nilai dari peubah lainnya.

Tabel 7. Hasil uji korelasi antar komponen pertumbuhan terhadap komponen hasil

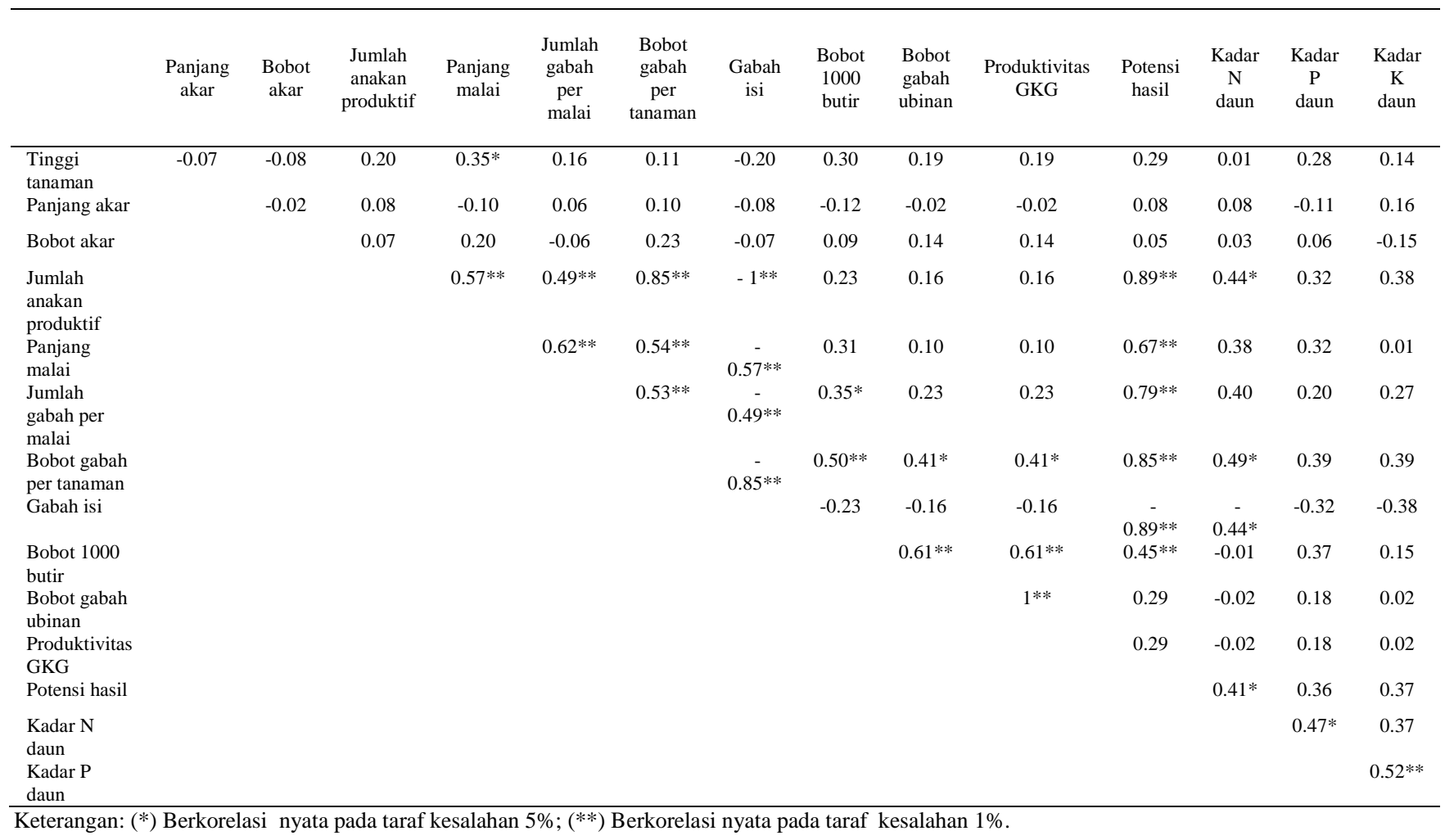

\section{Pembahasan}

Produktivitas GKG padi paling tinggi diperoleh dari aplikasi pupuk kandang secara bertahap yaitu pada saat 2 minggu sebelum tanam dan 4 minggu setelah tanam dengan penambahan pupuk hayati. Tingginya produktivitas padi akibat kombinasi aplikasi pupuk kandang pada saat 2 minggu sebelum tanam dan 4 minggu setelah tanam dengan pupuk hayati dipengaruhi oleh bobot 1000 butir dan bobot kering gabah/tanaman.
Hal ini ditunjukkan oleh adanya korelasi yang nyata dan positif dari kedua peubah tersebut. Semakin besar dari bobot 1000 butir dan bobot kering gabah/tanaman maka produktivitas padi akan semakin besar.

Rata-rata produktivitas GKG dari budidaya secara organik ini adalah sebesar 5.04 ton/ha dengan potensi hasil rata-rata 6.76 ton/ha hampir menyamai rata-rata produktivitas nasional pada tahun 2012 yaitu sebesar 5.08 ton/ha (Badan Pusat 
Statistik 2011). Meskipun demikian, produksi tersebut belum sesuai dengan deskripsi varietas yang dikeluarkan Balai Besar Penelitian Tanaman Padi (2009), varietas Ciherang mampu memproduksi 6.0 ton/ha dengan potensi hasil 8.5 ton/ha. Hasil penelitian ini menunjukkan bahwa pertumbuhan dan hasil padi yang dibudidayakan secara organik yang berkelanjutan sudah hampir setara dengan rata-rata hasil padi yang ditanam secara konvensional.

Jumlah gabah/malai tertinggi adalah pada aplikasi pupuk kandang 6 minggu setelah tanam tanpa pupuk hayati. Tingginya jumlah gabah per malai tidak berkorelasi dengan produktivitas GKG padi. Hal ini disebabkan nilai persentase gabah isi dari perlakuan tersebut adalah yang paling rendah (meskipun tidak berbeda nyata) dan bobot 1000 butirnya bukan yang paling tinggi.

Perlakuan aplikasi pupuk secara bertahap yaitu 2 minggu sebelum tanam dan 4 minggu setelah tanam dengan pupuk hayati memiliki bobot gabah yang lebih besar daripada perlakuan lainnya sehingga produktivitasnya menjadi lebih tinggi meskipun jumlah anakan produktif, panjang malai, dan jumlah gabah per malai lebih kecil daripada perlakuan lainnya. Perlakuan aplikasi pupuk 2 minggu sebelum tanam dan 4 minggu setelah tanam dengan pupuk hayati memiliki produktivitas yang lebih baik karena unsur hara pada tanaman diberikan 2 kali pada saat sebelum tanam dan setelah tanam sehingga unsur hara pada pertumbuhan vegetatif dan generatif tanaman dapat tersedia lebih baik.

Perlakuan aplikasi pupuk kandang 6 minggu setelah tanam memperlihatkan gejala defisiensi unsur hara pada saat pengamatan 5 minggu setelah tanam. Rendahnya nilai dari warna daun yang diamati dengan bagan warna daun dapat menunjukan gejala defisiensi unsur hara tersebut. Menurut Wahid (2003) batas kritis untuk padi pindah tanam yaitu pada skala 4 BWD. Aplikasi pupuk kandang 6 minggu setelah tanam diduga terlambat untuk memenuhi kebutuhan hara tanaman, akibatnya persentase gabah isinya rendah meskipun jumlah gabah per tanamannya tinggi.

Aplikasi pupuk hayati kurang efektif dalam meningkatkan pertumbuhan tanaman padi pada percobaan ini. Tidak berbedanya hasil yang didapatkan dapat disebabkan kandungan hara dan mikroorganisme pada pupuk hayati sudah terdapat di dalam pupuk kandang. Meskipun demikian, aplikasi pupuk hayati menyebabkan produksi padi yang lebih tinggi.

Efisiensi pengerjaan yang paling baik adalah pemberian pupuk kandang 2 minggu sebelum tanam tanpa pupuk hayati. Hal ini disebabkan tanaman tidak perlu diberi pupuk hayati dan pupuk kandang hanya perlu diberikan satu kali pada saat sebelum tanam sehingga tenaga kerja lebih efisien dan tanaman tidak terinjak saat diberi pupuk.

Tingginya produktivitas dari aplikasi pupuk kandang 2 minggu sebelum tanam dan 4 minggu setelah tanam dengan tambahan pupuk hayati lebih menguntungkan secara ekonomi pada luasan lahan yang luas daripada aplikasi pupuk kandang pada saat 2 minggu sebelum tanam tanpa pupuk hayati. Banyaknya biaya dari tenaga kerja dan biaya pembelian pupuk hayati dapat tertutupi dengan penjualan hasil panen yang tinggi.

Aplikasi pupuk organik yang berkelanjutan terbukti meningkatkan produktivitas. Menurut Nurrahma (2012) perlakuan pupuk organik pada padi di lahan yang sama pada tahun sebelumnya hanya menghasilkan produktivitas padi sekitar 2 ton/ha sedangkan pada percobaan ini produktivitasnya dapat mencapai 5.04 ton/ha.

\section{KESIMPULAN}

Produktivitas gabah kering giling tertinggi diperoleh dari aplikasi pupuk kandang secara bertahap pada 2 minggu sebelum tanam dan 4 minggu setelah tanam, masing-masing dengan dosis 5 ton/ha; dikombinasikan dengan pemberian pupuk hayati. Produksi padi juga dapat dilakukan dengan pemberian 10 ton/ha pupuk kandang 2 minggu sebelum tanam tanpa pupuk hayati.

\section{DAFTAR PUSTAKA}

[BPS] Badan Pusat Statistik (ID). 2010. Tabel Luas Panen- Produktivitas Produksi Tanaman Padi Seluruh Provinsi.[Internet]. [diunduh 201113 Oktober]. Tersedia pada: http://bps.go.id/

[BBP Padi] Balai Besar Penelitian Tanaman Padi. 2009. Deskripsi Varietas Padi. Balai Besar Penelitian Tanaman Padi. Subang (ID): BBP Padi Pr. "105 hlm".

[Balittan] Balai Penelitian Tanah (ID). 2005. Petunjuk Teknis: Analisis Kimia Tanah, Tanaman, Air dan Pupuk. Balai Penelitian dan Pengembangan Pertanian Departemen Pertanian. Bogor (ID): Balittan Pr. "143 hlm".

Bawlye J, Shyam M. 2008. Organik Rice. Laguna (Phil): IRRI Rice Knowledge Bank Pr. 
Dardak A. 1982. Ilmu Tanah. Pendidikan Diploma Petugas Pertanian Lapangan Terpadu. Medan (ID): USU Pr.

Gomez KA, Gomez AA. 1995. Prosedur Statistika untuk Penelitian Pertanian. Sjamsudin E, Baharsjah JS, penerjemah. Jakarta (ID): UI Pr. Terjemahan dari: Statistical Procedures for Agricultural Research. "698 p".

Nurrahma AHI. 2012. Pengaruh jenis pupuk dan dekomposer terhadap pertumbuhan dan produksi padi organik [skripsi]. Bogor (ID): Institut Pertanian Bogor.

Simatupang S. 1990. Pengaruh beberapa pupuk organik terhadap pertumbuhan dan produksi wortel. J Hort Indonesia. 2(1):15-19

Wahid AS. 2003. Peningkatan efisiensi pupuk nitrogen pada padi sawah dengan metode bagan warna daun. J Litbang Pertanian. 22(4):156-162. 